\title{
Protection for Indonesian Migrant Workers in Iraq in the Perspective of International Law
}

\author{
Yordan Gunawan ${ }^{1, *}$, Dwilani Irrynta ${ }^{2}$ \\ ${ }^{1,2}$ Faculty of Law, Universitas Muhammadiyah Yogyakarta, Indonesia \\ *Corresponding author. Email: yordangunawan@umy.ac.id
}

\begin{abstract}
Migrant workers who labor overseas, as contributors to the State' stock exchange, require protection from both international law and their own State. Despite the fact migrant workers are protected by international law, there are still countless situations involving migrant workers, such as the case of Indonesian migrant workers in Iraq. Recently, seven female workers in Iraq were detained in the basement. In addition, the other nine workers are imprisoned in Erbil. Therefore, the paper aims to analyse the protection of migrant workers from the perspective of international law in regard to such cases. The study employs secondary data in the form of primary and secondary legal texts to conduct normative legal research. The findings show there have been violations of the 1990 Convention on the Rights of All Migrant Workers and Members of Their Families, as well as the Protocol to Prevent, Suppress, and Punish Trafficking in Persons. Given that Iraq is not a signatory to the 1990 Migrant Workers Convention, the only settlement that Indonesia may pursue in such situations is through diplomatic measures against Iraq.
\end{abstract}

Keywords: migrant workers, legal protection, Indonesia, Iraq

\section{INTRODUCTION}

Globalization stimulates capital and investment flow to various parts of the world. Accordingly, there is labor mobility from one State to another. The reason for the labor migration is that investments established in other States usually need close supervision by the owner or investor. As a result, such migration is carried out in order to preserve company continuity and investment. To prevent legal issues and overuse of foreign employees, the government of a State must carefully and exhaustively identify the policies that will be implemented to preserve a balance between foreign and local workers. ${ }^{i}$ It is due to the fact foreign employees are becoming a larger and larger percentage of the workforce in all States throughout the world. ${ }^{\text {ii }}$

The attempts of the Indonesian government to achieve equal rights and duties for workers to better their standard of living include the deployment of Indonesian workers overseas. Indonesian workers can also contribute to the economy of the State as a result of such migration. ${ }^{\text {iii }}$ What should be emphasized is that the number of migrant workers increases in tandem with the number of current workers. The growth in labor migration is influenced by at least three major reasons. The first is the pull factor, which is brought about by changes in demography and labor demands in developed States. The push factor comes in second. It has to do with population, unemployment, and the effects of the financial crisis. Meanwhile, the third is the presence of inter-state networks based on family, culture, and history. ${ }^{\text {iv }}$

In almost all States, the needs of foreign workers deserve special attention. The specificity of their employment relationship makes them highly vulnerable to exploitation, abuse and forced labour. Many of them do not trust the authorities in their destination States and fear being deported for suing their service users. If the status of foreign workers is unclear, they would rather avoid the authorities as much as possible. In this case, they are almost completely dependent on service users. Accordingly, the service users will take advantage of their dependence by treating them as submissive workers and exploiting them. Service users may also rationalize the work of foreign workers as generosity to the foreign worker. ${ }^{\mathrm{v}}$ Such action can offset normal standards for the treatment of workers.

The administrations in numerous States have effectively created jobs which can be said that the workers are treated similar to prisoners. Foreign workers may stay, and live-in private households or facilities provided. However, they must leave the State if their contract with the service users has ended. Foreign workers are almost completely dependent on service users in terms of work, accommodation, food, and livelihood protection. ${ }^{\mathrm{vi}}$ Such a relationship is very unfair for foreign workers since it seems like they are indebted to the service users. ${ }^{\text {vii }}$ Most of the female, as well as male, migrant workers stated that the main reason for working abroad is that there is no opportunity to earn income in their home-State. In addition, there is a better possibility of getting higher earnings abroad despite the fact shelter or a safe place to live is not always provided. Workers are often victims of arbitrary and enforced deprivation of liberty at the hands of agencies. ${ }^{\text {viii }}$

Such a situation also occurs in the recent case that happened to several Indonesian migrant workers in Iraq. Allegedly, seven female migrant workers were held by their 
agents in the basement. Such information was revealed by one of the workers with the initials $\mathrm{AU}$ in a conversation via internet-based messaging. The worker in question claimed to have received information about the other seven workers who were being held captive from a friend's phone call at the agency's office before being confiscated. ${ }^{\text {ix }}$ In fact, it was also found in the near future that nine Indonesian female workers were imprisoned in Erbil on the grounds of having certain issues with their employers. Additionally, the workers in question are suspected of being victims of a human trafficking syndicate with the mode of employee placement. ${ }^{\mathrm{x}}$

As discussed above, it can be seen there are still numerous cases abroad in terms of torture experienced by migrant workers. Subsequently, many Indonesian migrant workers are caught in legal issues and have not been released by the Government of the Republic of Indonesia. Meanwhile, there has been a Convention ratified by the UN General Assembly on December 18, 1990, through Resolution No. 45/158. ${ }^{\text {i }}$ The Convention enshrines the essential elements of international law governing the protection of migrants. Furthermore, the treatment of foreigners overseas is linked to the investigation of the obligation of a State to protect its nationals abroad. The balance between a State' two fundamental rights has a significant impact on such issue. On the one hand, the State has the freedom to exercise jurisdiction inside its own borders, free of external oversight. The State in question, on the other hand, has the right to defend its nationals when they are overseas.

The Indonesia Government provides legal protection for their Migrant Workers through Law No. 39 of 2004 on the Placement and Protection of Indonesian Migrant Workers Abroad. ${ }^{\text {xii }}$ However, in reality, there are still numerous cases that occur abroad in terms of torture experienced by migrant workers. Moreover, there are still migrant workers who are caught in legal issues and have not been released by the Government of the Republic of Indonesia. They are still seen as a commodity to meet market demand and are not seen as decent people who work abroad that must be protected. Such commodity is reflected in the lack of provisions concerning protection under the Law. Consequently, the rights of those migrant workers to be protected by law within the States where they work are neglected.

Furthermore, in terms of migrant worker protection under international law, there is the United Nations General Assembly passed Resolution No. 45/158 in New York on December 18, 1990, ${ }^{\text {xiii }}$ which established legal protection by enacting the International Convention on the Protection of All Migrant Workers and Members of Their Families xiv (hereinafter referred to as the 1990 Migrant Workers Convention). In an effort to enforce legal protection for migrant workers, the UN issues conventions on the subject through the International Labor Organization (ILO). ${ }^{\mathrm{xv}}$ In addition, Indonesia is committed to implementing the Protocol to Prevent, Suppress and Punish Trafficking in Persons, especially Women and Children, by issuing Law No. 21 of 2007 on the Eradication of the Criminal Act of
Trafficking in Persons as one of the efforts to overcome the rampant cases of human trafficking which cannot be separated from Transnational Organized Crime related to the protection efforts for migrant workers.

As mentioned above, the paper aims to analyse the current case of Indonesian migrant workers in Iraq, which is then associated with the protection of migrant workers from the perspective of international law. It is due to the fact there are still numerous cases involving migrant workers, particularly the Indonesian workers in Iraq, although there are already international legal rules that protect migrant workers.

\section{RESEARCH METHOD}

The paper is conducted through normative legal research by examining the laws and regulations that apply to related particular legal issues discussed. Normative research is often referred to as doctrinal research since the objects of study are documents of legislation and library materials. The research is conducted in an effort to find secondary data consisting of primary legal materials, including related laws and regulations, as well as secondary legal materials that provided explanations regarding the primary legal materials, such as books, literature, research results and scientific works.

\section{PROTECTION OF MIGRANT WORKERS UNDER INTERNATIONAL LAW}

In the realm of international law, there are several definitions of migrant workers. According to the ILO Convention No. 97 of 1949 on Migration for Employment, a migrant worker is a person who migrates from one State to another for the purpose of work or being employed as well as a person who is regularly recognized as a migrant for work. Meanwhile, the International Convention on the Protection of Migrant Workers and Members of Their Families ${ }^{\mathrm{xvi}}$ defines migrant workers as persons who will, are currently, or have been involved in an activity that generates wages for themselves in a State where they are not a citizen of the State in question.

There are numerous ILO Conventions related to the Protection of Migrant Workers. Under the Equality of Treatment (Accident Compensation) Convention No. 19 of 1925, each Member State that ratifies the Convention shall guarantee every citizen of any other Member State who suffers injuries as a result of work accidents that occur within the territory of the Member State in question receives the same treatment in terms of occupational accident benefits as their own citizens. Regardless of where their place of residence is, foreign workers and their families must be granted such a guarantee. ${ }^{\text {xvii }}$ Furthermore, the action to be taken in regard to payments made by the Member State or its citizens outside the territory of the Member State in question shall be regulated. If it is necessary, the Member States concerned may establish a special agreement between them.

Furthermore, the Discrimination (Employment and Occupation) Convention No. 111 of 1958 states that every 
Member State implementing the Convention shall seek a means to establish and pursue a national policy aimed at promoting equality of opportunity and treatment in respect of employment and occupation in a manner appropriate to the national circumstances and practices of the Member State in question to eliminate any discrimination on such matters. In addition, each Member State shall also make efforts to establish cooperation from employers' and workers' organizations as well as other relevant bodies, in order to promote acceptance and adherence to such policy, encourage the direct supervision of such policy by the national authorities of the Member State in question, and also set down what actions have been taken and the results achieved by taking such action in its annual reports on the adoption of the Convention.

There is also the Equality of Treatment (Social Security) Convention No. 118 of 1962, which covers the nine important branches of social security, namely (1) medical care, (2) sickness benefits, (3) maternity benefit, (4) invalidity benefit, (5) old-age benefits, (6) survivors' benefits, (7) employment injury benefits, (8) unemployment benefits, and (9) family benefits. ${ }^{\text {xviii }}$ Through the Convention, every Member State is required to provide citizens of other Member States with equal treatment in terms of social security, same as their own citizens within the territory of the Member State in question. Besides that, refugees and others who do not have citizenship shall also be treated equally.

A ratifying Member State may, however, limit the application of the Convention to certain branches. In addition, the entitlements to benefits that are subject to resident requirements under national legislation cannot be applied to non-citizens. Subsequently, a Member State of the Convention shall also ensure provisions for overseas allowances, in a particular branch, both for the citizens of its own as well as other States which have accepted the obligations stipulated under the Convention for the same branch regardless of the place of residence of the beneficiary. Such principles must also be applied to refugees and stateless people without regard for reciprocity.

Furthermore, given the important role of private employment agencies in the recruitment and placement of migrant workers, as well as the need to protect migrant workers from fraudulent and abusive practices, the ILO Private Employment Agencies Convention No. 181 of 1997 is presented as a guide to drafting a legal framework to address illegal recruitment practices and human trafficking, particularly of women and girls. The objectives of the Convention are to allow private employment agencies to operate, to protect workers who use their services from abuse, and to ensure that these workers are entitled to the fundamental rights provided under labor standards, as well as the provisions relating to recruitment and placement under the Convention No. 97 of 1949 on Migration for Employment.

The Convention specifies that Member States shall guarantee that private employment agencies treat workers without discrimination in order to promote equality of opportunity and treatment in obtaining employment and occupation. Discrimination on the basis of race, color, sex, religion, political opinion, national background, social background $^{\mathrm{xix}}$ or any other basis protected by domestic law and practice is prohibited. Furthermore, with some restrictions, private employment agencies may not collect any fee or due, in whole or in part, to workers, either directly or indirectly.

Following that, Member States that have signed the Convention shall take means to ensure that migrant workers recruited or placed on their territory by private employment agencies are adequately protected. ${ }^{\mathrm{xx}}$ Such means must include regulations and provisions along with sanctions, such as prohibiting private employment agencies from partaking in fraudulent acts and fraud. Additionally, the relevant Member States must seek bilateral agreements to prohibit fraudulent activities in recruitment, placement, and employment.

Another regulation under international law that provides protection for migrant workers is the 1990 Migrant Workers Convention. The Convention was declared in New York on December 18, 1990 and entered into law on July 1, 2003. As a member of the UN, Indonesia signed the Convention on September 22, 2004. The 1990 Migrant Workers Convention is the broadest framework in international law and includes the protection of people who plan to become migrant workers, are working abroad, or have finished working abroad and return to their home State. The 1990 Migrant Workers Convention provides an internationally definition of the term migrant worker and is divided into frontier workers, seasonal workers, seafarers, workers in offshore installations, mobile workers, project workers, workers with specific jobs and selfemployed that can be applied in any State around the world. ${ }^{\mathrm{xxi}}$

The 1990 Migrant Workers Convention aims to protect the rights of workers while they are working in States other than their home-State. The protection provided for in the Convention emphasizes the role of legal migrant workers' documents. A valid migrant worker document will ensure that there are no violations, such as a violation of the age limit for migrant workers, in the process of labor migration. Such a document will also be useful to minimize the occurrence of human trafficking and smuggling practices.

The Migrant Workers Convention of 1990 governs a number of critical issues, including the establishment of basic requirements for the protection of civil, political, economic, social, and cultural rights of all migrant workers and members of their families. xxii States are encouraged to harmonize their laws with the universal requirements under the Convention. Furthermore, the Convention recognizes migrant workers' contributions to the economies ${ }^{x x i i i}$ and societies of the States in which they work, as well as the development of their homeStates. Subsequently, the Convention establishes a set of rules for the protection of migrant workers as well as the responsibilities of the States involved, encompassing the States of origin, transit, and employment. ${ }^{\text {xxiv }}$ Moreover, the Convention prohibits and eliminates all forms of exploitation of migrant workers and their families at all stages of the 
migration process, including human trafficking. As a result, the Convention not only protects migrant workers, but also the interests of receiving States in terms of restricting access to occupational categories to protect their citizens.

The Convention adopted by the UN General Assembly on December 18, 1990, through Resolution No. 45/158 was originally an initiative of the States of origin of migrant workers to establish a more specific standard of protection. The Convention is the result of the study, dialogue and deepening between two sides of thought, both representing the interests of the State of origin of the migrant worker and the State of destination. The 1990 Migrant Workers Convention covers the essential provisions regarding the protection of migrants internationally. Additionally, in connection with the understanding of transnational crime that international law consists of elements of domestic law and international law, it is stated as "dissolve traditional dichotomies between two". In other words, the Convention itself has provided guarantees for the state to establish a policy for the acceptance of migrant workers and members of their families, which is deemed to be in accordance with domestic law.

Furthermore, Article 7 of the 1990 Migrant Workers Convention constitutes that States must respect and ensure that all migrant workers and members of their families ${ }^{\mathrm{xxv}}$ within their territory or subject to their jurisdiction enjoy the rights guaranteed by the Convention without any form of discrimination $^{\mathrm{xxvi}}$, in accordance with their human rights instruments. Subsequently, Part VI of the Convention stipulates a number of obligations on the Member States to promote good, equal, humane and lawful conditions ${ }^{\text {xxvii }}$ for the international migration of migrant workers and their families. Such requirements include policymaking on migration, exchange of information with the other Member States, provision of information to employers, workers, and their organizations on legal as well as regulatory policies and assistance to migrant workers and members of their families.

In addition to the General Assembly Resolution 53/111 of December 9, 1998, the Assembly established an intergovernmental ad hoc committee without boundaries. The aim is to elaborate a comprehensive international convention against transnational organized crime as well as to elaborate an international instrument dealing with transnational organized crime trafficking in women and children.

\section{CASE OF ILLEGAL INDONESIAN WORKERS IN IRAQ}

As mentioned earlier, the paper is intended to analyse the current cases of Indonesian migrant workers in Iraq, particularly the case of seven female migrant workers held by their agents in the basement as well as the other nine workers imprisoned in Erbil. Such cases were revealed by one of the Indonesian migrant workers in Iraq with initial $\mathrm{AU}$ in a conversation via internet-based messaging. The worker in question claimed to have received information about the seven migrant workers being held captive from a friend' phone call at the agency office before being confiscated. ${ }^{\text {xxviii }}$

It was begun when the seven colleagues of AU were sent home by their employers where one of them was sick. After that, the seven of them devised a plan to escape to the Indonesian Embassy or the Indonesian Consulate General in Erbil since the Embassy in Baghdad was quite far away. Those seven migrant workers then received direction from Slemani instead of Erbil. In Slemani, there were already people who waited for them, namely Amir and Aram- an Iraqi lawyer who works at the Indonesian Embassy. However, it turned out that the seven workers were instead taken to the agency' office in Slemani, not to the Embassy nor the Consulate General. Subsequently, their handphones were confiscated while they were held in the basement. Actually, the seven migrant workers were visited by the Indonesian Embassy. However, there was no evidence that anyone was being held. The worker who reported the case, AU, alleged that those workers might have been transferred prior to the visit to the Embassy. ${ }^{\text {xix }}$

Meanwhile, in the case of nine Indonesian female workers imprisoned in Erbil due to certain issues with their employers, the migrant workers are suspected of being victims of a trafficking syndicate with the mode of placement of workers. The case was revealed by Iis Lisnawati, a former Indonesian migrant worker from Cirebon, West Java, through a video received by the news portal, Pojoksatu.id. Prior to her return to Indonesia, she was also imprisoned on the grounds of the report of her employer. However, she did not spill the details because she was imprisoned. The former worker in question just admitted that she was slandered for something she did not do. Furthermore, according to her, numerous Indonesian female workers in Iraq are imprisoned on charges they did not commit. Most of them who are imprisoned are allegedly being victims of human trafficking. She also considered people in Erbil are cruel due to the fact they often torture Indonesian migrant workers who work as household assistants. ${ }^{\mathrm{xx}}$ Most of the employers in Erbil often do not provide food to the migrant workers, which consequently leads them to experience hunger.

One of the Indonesian migrant workers who became victims of human trafficking is May Purbaningrum, a migrant worker from Serang, Banten. Currently, she works in Erbil, Iraq. However, May admitted to working in Iraq on the grounds that she was persuaded by a person named Dewi, who offered her a job as a domestic helper. Post the arrival in Erbil, May was actually sold by a labor agency. Subsequently, she sought some help from the Indonesian government and the Indonesian Advocacy Agency so that she could return to Indonesia. ${ }^{\mathrm{xxxi}}$ 


\section{THE ROLE OF THE INDONESIAN GOVERNMENT IN PROVIDING AND ENFORCING PROTECTION FOR MIGRANT WORKERS}

In the perspective of international law, the case of Indonesian Migrant Workers in Iraq who were held by agents in the basement is considered to have violated the 1990 Migrant Workers Convention. Comprehensively, the Convention contains the legal protection and human rights of migrant workers ${ }^{x x x i i}$ which consists of 93 Articles that regulate the guarantee of protection for all migrant workers and family members, either documented or not. The provisions of Article 10 affirm that no migrant worker and members of their families may be subjected to torture or other cruelty, inhuman, degrading treatment, or punishment. ${ }^{\mathrm{xxxiii}}$ The Convention makes a breakthrough in formulating legal and human rights protections for legal and undocumented migrant workers as stipulated under Article 5 of the Convention. ${ }^{\text {xxxiv }}$ Furthermore, the provisions of Article 7 confirm that States undertake to respect and ensure that all migrant workers and members of their families within their territory or subject to their jurisdiction are entitled to the rights set forth in the Convention, in accordance with their human rights instruments.

On April 12, 2012, Indonesia ratified the 1990 Migrant Workers Convention. ${ }^{\mathrm{xxy}}$ However, Iraq did not sign nor ratify the Convention. Even so, Iraq is one of the legitimate Member States of the ILO. Therefore, Indonesia may take legal remedies through diplomacy efforts in regard to the current cases that occurred to the Indonesian female migrant workers. Exceedingly there is a number of violations of human rights have been carried out in such cases.

Furthermore, the 1990 Migrant Workers Convention can also be imposed in the case of nine female workers suspected of being victims of a trafficking syndicate with the mode of placement of workers who were then imprisoned due to certain issues with their employers. It is on the grounds that the Convention has provided protection for all migrant workers and family members. ${ }^{\text {xxxvi }}$ In addition, the Palermo Protocol stipulates that a comprehensive international strategy involving governments of origin, transit, and destination is urgently needed in order to prevent and eradicate human trafficking, particularly of women and children. Measures to combat human trafficking, punish traffickers, and protect victims of human trafficking, as well as their internationally recognized human rights, are all included.

As mentioned earlier, the General Assembly, through the Resolution 53/111 of December 9, 1998, decided to establish an intergovernmental ad hoc committee without Boundaries to elaborate a comprehensive international convention against transnational organized crime as well as an international instrument dealing with trafficking in persons. Accordingly, the States that are members of the Protocol believes that adding the UN Convention against transnational organized crime with an international instrument to prevent, eradicate and punish trafficking in persons, especially women and children, will be very useful in preventing and combating such crimes.

Subsequently, the Protocol to Prevent, Suppress and Punish Trafficking in Persons was adopted through UN Resolution A/RES/55/25. It is an additional protocol to the UN Convention on Transnational Organized Crime which must always be interpreted simultaneously with the Convention against Transnational Organized Crime. The Protocol entered into force on December 25, 2003, after the 40th State ratified it. Then, Indonesia ratified the Protocol on March 5, 2009, through Law No. 14 of 2009 on Ratification of the Protocol to Prevent, Suppress, and Punish Trafficking in Persons, Especially Women and Children, Supplementing the United Nations Conventions Against Transnational

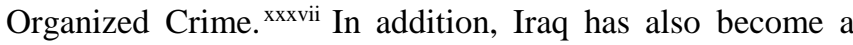
Member State of the Protocol.

Therefore, it can be seen that Indonesia may take legal action through diplomatic efforts in regard to the current cases of Indonesian migrant workers in Iraq in order to provide protection for migrant workers. Migrant workers and members of their families must be protected by law and have the right to life even if they are outside their home-State. ${ }^{\text {xxxviii }}$ In addition, the ILO Convention also prohibits slavery or forced labor ${ }^{\mathrm{xxxix}}$ against migrant workers as well as members of their families. Forced labor in this case, however, does not include that which is normally required of persons detained by lawful order from a court or on persons undergoing parole from detention.

At the national level, Indonesia is obliged to guarantee and protect the rights of its citizens to obtain equal employment and treatment before the law. It is in accordance with Article 27 Paragraph (2) of the 1945 Constitution of the Republic of Indonesia, which stipulates that every citizen has the right to work and a decent living. Furthermore, Article 28D paragraph (1) of the Constitution emphasizes that everyone has the right to recognition, guarantee, protection and fair legal certainty and equal treatment before the law. However, the enforcement of human rights in its implementation is not sufficient to only stipulate Articles under the Constitution as a form of guarantee for their protection. Instead, the guarantee must also be contained in other laws and regulations as well as international human rights instruments and realized within law enforcement. ${ }^{\mathrm{xl}}$

In the perspective of international law, it is stated that a State has an obligation to protect its citizens in any other State they live in. ${ }^{x l i}$ It is in accordance with Diplomatic Protection. The concept of such protection is that any action taken by a State against another State in respect of injury to the person or property of national caused by an internationally wrongful act or omission attributable to the latter State. ${ }^{\text {xlii }}$

Following that, three requirements must be completed in order to provide diplomatic protection to citizens, ${ }^{\text {xliii }}$ of whom are migrant workers in this case. To begin, an International 
Wrong, specifically a State of Origin, must give protection to its citizens who are abroad in the event that the citizens in question violate international law. The Exhaustion of Local Remedies is the second. ${ }^{\text {xliv }}$ If a citizen of a State has used local legal remedies in the receiving State, the former State must provide legal assistance to the citizen in question in order to sue the later State. Meanwhile, the third is the Link of Nationality, ${ }^{x l v}$ which provides diplomatic protection to citizens in the case of an act of international law violation by another State. Such conditions are consistent with the principle of passive citizenship, which refers to a State' authority over persons who break the law in another State' territory or jurisdiction where the repercussions of breaking the law affect their citizens. As a result, the State where the violation of the law occurs lacks the jurisdiction to punish, but the State whose citizens are impacted by the violation of the law does.

Furthermore, the problem of state jurisdiction arises due to the fact each State is a sovereign member within the international community. Additionally, the relations prevailing in the international community occur beyond the boundaries of one State. A similar situation occurs when migrant workers seek opportunities to improve their economics in other States without any protection. ${ }^{x l v i}$ Accordingly, a question arises how far the jurisdiction of a State over the guarantee of the protection of individual rights is. .lvii

Two principles in international law are used to underlie state jurisdiction in international relations, namely the territorial principle and the expanded territorial principle. The former stipulates that state jurisdiction applies to individuals residing within its territory. ${ }^{x l v i i i}$ Territorial jurisdiction is enforced based on the State's sovereignty over its territory. ${ }^{\text {xlix }}$ On the other hand, the later stipulates that state jurisdiction also applies in other States that are outside its territory as long as it is related to the State in question. Such understanding opens the opportunity for the application of the expanded territorial principle when migrant workers residing in other States outside the territory of their home-State receive protection and guarantees for that.

In the context of the role of a State through its government, the establishment of international law governing the protection of the rights of migrant workers can be elaborated and harmonized with the provisions under Article 38 paragraph (1) of the Statute of the International Court of Justice. It provides that the Court uses four sources of international law in adjudicating cases, ${ }^{1}$ namely, (1) international treaties, both general and specific, (2) international custom, (3) recognized general legal principles by civilized States, and (4) Court decisions as well as experts' opinions as an additional source of international law.

If it is associated with the current Indonesian migrant workers in Iraq, the Government must take fundamental and strategic measures to ensure that the mistreatment of Indonesian workers can be ended. Based on the analysis in the paper, there are at least three measures that may be taken.
First, the Indonesian representatives abroad must strictly monitor the legal process for the inhumane actions of employers who commit abuse or any other related action. Monitoring is essential in order to give a deterrent effect. Second, the Government must take serious action in dealing with the Indonesian Migrant Worker Service Companies, which act as the agent for sending workers. Third, the Government must be able to negotiate and stipulate bilateral agreements with any State receiving migrant workers. The bilateral agreement accommodates the provisions of the 1990 Migrant Workers Convention.

\section{CONCLUSION}

It can be concluded that the State plays a crucial role in shaping the provisions for the protection of migrant workers. Besides the fact the State is the main subject of international law, it also has an obligation not to discriminate against any individual regardless of which State they come from. In the perspective of international law, the current cases of Indonesian migrant workers in Iraq have violated the 1990 Migrant Workers Convention as well as Protocol to Prevent, Suppress and Punish Trafficking in Persons. By looking at the legal facts that Iraq is not a party to the Convention, the legal remedies Indonesia may take regarding the cases are through diplomatic efforts against Iraq.

\section{REFERENCES}

[1] Aining, Zhang. 2018. "Predicaments and Countermeasures of the Protection of Migrant Workers' Human Rights.” J. Hum. Rts 17: 223.

[2] Almutairi, Abdullah M. 2018. "The Domestic Application of International Human Rights Conventions in Saudi Arabia and the Need to Ratify Conventions on Migrant Workers." Middle Eastern Studies 54, No. 1: 4867.

[3] Arpangi. 2018. "Legal Protection on Indonesian Labor in Abroad.” International Journal of Law Reconstruction 2, No. 1: 53-62.

[4] Caxaj, C. Susana, and Amy Cohen. 2021. "Relentless Border Walls: Challenges of Providing Services and Supports to Migrant Agricultural Workers in British Columbia." Canadian Ethnic Studies 53, No. 2: 41-67.

[5] Coppola, Nicolamaria. 2018. "Gendering Migration: Women, Migratory Routes and Trafficking." New England Journal of Public Policy 30, No. 2 (2018): 1-11.

[6] Denza, Eileen. 2018. "Nationality and Diplomatic Protection." Netherlands International Law Review 65, No. 3: 463-80.

[7] Dewi, Anggia Utami, and Adityo Darmawan Sudagung. 2017. "Indonesia's Migrant Domestic Workers within ASEAN Community Framework: A Societal and Economic Security Approach." Intermestic: Journal of International Studies 2, No. 1: 20-35.

[8] Elvianti, Witri, and Jihan Djafar Sidik. 2018. "The 
Consignment of Indonesian Migrant Workers in Saudi Arabia and Its Resilience: Examining the Impacts of Indonesia's Moratorium Policy (2011-2015)." Andalas Journal of International Studies (AJIS) 7, No. 1: 14-32.

[9] Equality of Treatment (Social Security) Convention, 1962 (No. 118).

[10] Gaja, Giorgio. 2019. "General Principles in the Jurisprudence of the ICJ." Queen Mary Studies in International Law 37: 35-43.

[11] Gunawan, Yordan, and Zulfiani Ayu Astutik. 2019. "The Importance of Bilateral Agreement on Mandatory Consular Notification for Indonesia: Tuti Tursilawati Execution.” Jurnal Hukum Novelty 10, No. 2: 85-100.

[12] Iacob, Oana-Adriana. 2020. "Principles Regarding State Jurisdiction in International Law." LESIJ-Lex ET Scientia International Journal 27, No. 1: 21-31.

[13] Jacobs, Cody J. 2018. "In Defense of Territorial Jurisdiction." U. Chi. L. Rev 85: 1589.

[14] Jeon, Seung-Cheol. 2018. "Foreign Workers in The Korean Labour Market: Current Status and Policy Issues." BIS Papers, No. 100: 209-21.

[15] Maharani Wibisono, Lutecia Zahra, and Diani Sadiawati. 2021. "Protection of Migrant Workers in Suriname: How Do Indonesian Representatives Implement International Labour Organization Conventions?" Udayana Journal of Law and Culture 5, No. 2: 138-52.

[16] Marina, Sharpe. 2018. "Mixed Up: International Law and the Meaning(s) of "Mixed Migration"." Refugee Survey Quarterly 37, No. 1: 116-38.

[17] Nuraeny, Henny. 2017. "Trafficking of Migrant Workers in Indonesia: A Legal Enforcement and Economic Perspective of Prevention and Protection Efforts." European Research Studies Journal 20, No. 4: 16-26.

[18] Palmer, Wayne, and Antje Missbach. 2019. "Enforcing Labour Rights of Irregular Migrants in Indonesia." Third World Quarterly 40, No. 5: 908-25.

[19] Piper, Nicola, Stuart Rosewarne, and Matt Withers. 2017. "Migrant Precarity in Asia: Networks of Labour Activism for a Rights-based Governance of Migration." Development and Change 48, No. 5: 1089-1110.

[20] Pojoksatu.id. "9 TKW Irak Dipenjara, Diduga Korban Perdagangan Orang." Accessed from https://pojoksatu.id/news/berita-nasional/2021/09/15/9tkw-irak-dipenjara-korban-perdagangan-orang/ on September $28^{\text {th }} 2021$ at 3:58 $\mathrm{pm}$.

[21] Pojoksatu.id. "Ini Daftar Nama 9 TKW Yang Dipenjara Di Erbil Irak." Accessed from https://pojoksatu.id/news/berita-nasional/2021/09/16/inidaftar-nama-9-tkw-yang-dipenjara-di-erbil-irak/\# on September $20^{\text {th }} 2021$ at 2:37 pm.

[22] Pojoksatu.id. "Pengakuan, Diduga Ada 7 TKW Di Irak Disekap Agen Di Ruang Bawah Tanah.” Accessed from https://pojoksatu.id/news/berita- nasional/2021/09/17/pengakuan-diduga-ada-7-tkw-diirak-disekap-agen-di-ruang-bawah-tanah/ on September $28^{\text {th }} 2021$ at $3: 43 \mathrm{pm}$.

[23] Rahayu, Devi. 2018. "Migrant Workers' Village as an Effort to Strengthen The Rights of Indonesian Migrant Workers." SHS Web of Conferences 54.

[24] Rahmawati, Mety. 2019. "Indonesian Worker Protection from Labour Exploitation in Singapore." Jurnal Dinamika Hukum 19, No. 1 (2019): 169-85.

[25] Ruhs, Martin. 2017. "Rethinking International Legal Standards for the Protection of Migrant Workers: The Case for a 'Core Rights' Approach.” AJIL Unbound 111: 172-76.

[26] Santoso, M. Iman. Hukum Pidana Internasional. Bandung: Pustaka Reka Cipta, 2013.

[27] Sulaksono, Endro. 2018. "The Patterns of Human Trafficking on Indonesian Migrant Workers: Case Study of Riau Islands and Johor Border Crossing." MASYARAKAT: Jurnal Sosiologi 23, No. 2 (2018): 167 86.

[28] Venturi, Denise. 2018. “Migrant Workers' Rights in Focus: Placing the UN Convention on Migrant Workers in the European Human Rights' Framework." Labour Migration in Europe 2: 17-43.

[29] Venturi, Emily. 2018. "Obstacles and Opportunities in Africa for the Ratification of the International Convention on the Protection of the Rights of All Migrant Workers and Members of Their Families." Global Africana Review $2: 41-48$.

[30] Wahab, Harlida Abdul, and Nik Ahmad Kamal Nik Mahmod. 2020. "Defining Employment Discrimination in Malaysian Legal Context." Pertanika Journal of Social Sciences and Humanities 28, No. 1: 379-95.

[31] Wang, Chieh-Hsuan, Chien-Ping Chung, and Jen-Te Hwang. 2019. "The Impact of Minimum Wages and Foreign Domestic Workers in Taiwan." Australian Economic Papers 58, No. 2: 168-93.

[32] Widyawati, Anis. 2018. "Legal Protection Model for Indonesian Migrant Workers." Journal of Indonesian Legal Studies 3, No. 02: 291-304. 
${ }^{i}$ Chieh-Hsuan Wang, Chien-Ping Chung, and Jen-Te Hwang, 2019, “The Impact of Minimum Wages and Foreign Domestic Workers in Taiwan," Australian Economic Papers 58, No. 2: 168 - 193.

ii Seung-Cheol Jeon, 2018, "Foreign Workers in The Korean Labour Market: Current Status and Policy Issues," BIS Papers, No. 100: 209-221.

iii Anggia Utami Dewi and Adityo Darmawan Sudagung, 2017, "Indonesia's Migrant Domestic Workers within ASEAN Community Framework: A Societal and Economic Security Approach," Intermestic: Journal of International Studies 2, No. 1: 20-35.

iv Anis Widyawati, 2018, "Legal Protection Model for Indonesian Migrant Workers," Journal of Indonesian Legal Studies 3, No. 02: 291-304.

${ }^{v}$ C. Susana Caxaj and Amy Cohen, 2021, "Relentless Border Walls: Challenges of Providing Services and Supports to Migrant Agricultural Workers in British Columbia," Canadian Ethnic Studies 53, No. 2: 41-67.

vi Anggia Utami Dewi and Adityo Darmawan Sudagung, Op.cit.

vii Ibid.

viii Mety Rahmawati, 2019, "Indonesian Worker Protection from Labour Exploitation in Singapore," Jurnal Dinamika Hukum 19, No. 1: 169-85.

ix Pojoksatu.id, "Pengakuan, Diduga Ada 7 TKW Di Irak Disekap Agen Di Ruang Bawah Tanah," Accessed from https://pojoksatu.id/news/berita-

nasional/2021/09/17/pengakuan-diduga-ada-7-tkw-di-irak-

disekap-agen-di-ruang-bawah-tanah/ on September $20^{\text {th }}$, 2021 at 3:43 pm.

x Pojoksatu.id, "9 TKW Irak Dipenjara, Diduga Korban Perdagangan Orang," Accessed from https://pojoksatu.id/news/berita-nasional/2021/09/15/9-tkwirak-dipenjara-korban-perdagangan-orang/ on September $20^{\text {th }}, 2021$ at $3: 58 \mathrm{pm}$.

xi Nicolamaria Coppola, 2018, “Gendering Migration: Women, Migratory Routes and Trafficking," New England Journal of Public Policy 30, No. 2: 1-11.

xii Lutecia Zahra Maharani Wibisono and Diani Sadiawati, 2021, "Protection of Migrant Workers in Suriname: How Do Indonesian Representatives Implement International Labour Organization Conventions?," Udayana Journal of Law and Culture 5, No. 2: 138-52.

xiii Nicolamaria Coppola, Op.cit.

xiv Henny Nuraeny, 2017, "Trafficking of Migrant Workers in Indonesia: A Legal Enforcement and Economic Perspective of Prevention and Protection Efforts," European Research Studies Journal 20, No. 4: 16-26.

${ }^{\mathrm{xv}}$ Nicola Piper, Stuart Rosewarne, and Matt Withers, 2017, "Migrant Precarity in Asia: Networks of Labour Activism for a Rights - based Governance of Migration," Development and Change 48, No. 5: 1089 - 1110.

xvi Emily Venturi, 2018, "Obstacles and Opportunities in Africa for the Ratification of the International Convention on the Protection of the Rights of All Migrant Workers and Members of Their Families," Global Africana Review 2: 4148.

xvii Harlida Abdul Wahab and Nik Ahmad Kamal Nik Mahmod, 2020, "Defining Employment Discrimination in Malaysian Legal Context," Pertanika Journal of Social Sciences and Humanities 28, No. 1: 379-395.

xviii Article 2 of the Equality of Treatment (Social Security) Convention, 1962 (No. 118).

xix Harlida Abdul Wahab and Nik Ahmad Kamal Nik Mahmod, Op.cit.

${ }^{x x}$ Nicola Piper, Stuart Rosewarne, and Matt Withers, Op.cit. xxi Ibid.

xxii Emily Venturi, Op.cit.

xxiii Zhang Aining, 2018, "Predicaments and Countermeasures of the Protection of Migrant Workers' Human Rights," $J$. Hum. Rts 17: 223.

xxiv Denise Venturi, “Migrant Workers' Rights in Focus: Placing the UN Convention on Migrant Workers in the European Human Rights' Framework," Labour Migration in Europe 2 (2018): 17-43.

${ }^{x x v}$ Emily Venturi, Op.cit.

xxvi Harlida Abdul Wahab and Nik Ahmad Kamal Nik Mahmod, Op.cit.

xxvii Devi Rahayu, 2018, “Migrant Workers' Village as an Effort to Strengthen The Rights of Indonesian Migrant Workers," SHS Web of Conferences 54.

xxviii Pojoksatu.id, Op.cit.

xxix Ibid.

xxx Pojoksatu.id, "Ini Daftar Nama 9 TKW Yang Dipenjara Di Erbil Irak," Accessed from https://pojoksatu.id/news/beritanasional/2021/09/16/ini-daftar-nama-9-tkw-yang-dipenjaradi-erbil-irak/\# on September $20^{\text {th }}, 2021$ at 2:37 pm.

xxxi Ibid.

xxxii Martin Ruhs, 2017, "Rethinking International Legal Standards for the Protection of Migrant Workers: The Case for a 'Core Rights' Approach,” AJIL Unbound 111: 172-76. xxxiii Sharpe Marina, 2018, "Mixed Up: International Law and the Meaning(s) of "Mixed Migration"," Refugee Survey Quarterly 37, No. 1: 116-138.

xxxiv Abdullah M. Almutairi, 2018, “The Domestic Application of International Human Rights Conventions in Saudi Arabia and the Need to Ratify Conventions on Migrant Workers," Middle Eastern Studies 54, No. 1: 48-67.

xxxv Arpangi, 2018, "Legal Protection on Indonesian Labor in Abroad," International Journal of Law Reconstruction 2, No. 1: 53-62.

xxxvi Wayne Palmer and Antje Missbach, 2019, "Enforcing Labour Rights of Irregular Migrants in Indonesia," Third World Quarterly 40, No. 5: 908-25.

xxxvii M. Iman Santoso, 2013, Hukum Pidana Internasional (Bandung: Pustaka Reka Cipta), p. 151

xxxviii Sharpe Marina, Op.cit.

xxxix Emily Venturi, Op.cit.

xl Witri Elvianti and Jihan Djafar Sidik, 2018, "The Consignment of Indonesian Migrant Workers in Saudi Arabia and Its Resilience: Examining the Impacts of Indonesia's 
Moratorium Policy (2011-2015)," Andalas Journal of International Studies (AJIS) 7, No. 1: 14-32.

xli Endro Sulaksono, 2018, "The Patterns of Human Trafficking on Indonesian Migrant Workers: Case Study of Riau Islands and Johor Border Crossing," MASYARAKAT: Jurnal Sosiologi 23, No. 2: 167-86.

xlii Ibid.

xliii Yordan Gunawan and Zulfiani Ayu Astutik, 2019, "The Importance of Bilateral Agreement on Mandatory Consular Notification for Indonesia: Tuti Tursilawati Execution," Jurnal Hukum Novelty 10, No. 2: 85-100.

xliv Eileen Denza, 2018, "Nationality and Diplomatic Protection," Netherlands International Law Review 65, No. 3: 463-80. xlv Yordan Gunawan and Zulfiani Ayu Astutik, Op.cit.

xlvi Zhang Aining, Op.cit.

xlvii Henny Nuraeny, Op.cit.

xlviii Oana-Adriana Iacob, 2020, "Principles Regarding State Jurisdiction in International Law," LESIJ-Lex ET Scientia International Journal 27, No. 1: 21-31.

xlix Cody J Jacobs, 2018, "In Defense of Territorial Jurisdiction," U. Chi. L. Rev 85: 1589.

${ }^{1}$ Giorgio Gaja, 2019, "General Principles in the Jurisprudence of the ICJ," Queen Mary Studies in International Law 37: 3543. 